\title{
Rebuttal for comment: Big sagebrush pro vs con
}

\author{
F.C. HINDS
}

I am writing in response to comments made by Bruce L. Welch regarding a paper published in the Journal of Range Management titled "Mountain big sagebrush browse decreases dry matter intake digestibility, and nutritive quality of sheep diets" by Ngugi, et. al. 1995. Vol. 48, Number 6 pages $487-497$. Dr. Welch expresses 2 concerns: 1) bias in the literature review and 2) the methods used to conduct the research.

Regarding the first concern, to suggest the review of literature was biased is affectation. However, to say the review of literature was incomplete is no doubt Dr. Welch's feeling. I would challenge any author, Dr. Welch included, when writing for a scientific journal, except a review article, to compose a review of literature, with the space restraints imposed by policy, totally satisfactory to all readers. I too find manuscripts lacking references I would prefer to see cited but I wasn't the reviewer of the manuscript prior to publication. Finally, I can assure Dr. Welch there was no bias in selecting the literature to be cited and regret we did not include references he feels are important.

Most of Dr. Welch's concerns relate to the procedures used in conducting the research such as 1) animal adaptation to sagebrush, 2) the agreement or lack of agreement between in vivo and in vitro results, 3) the relative amount of lignin in plants, 4) the loss of volatiles during prehension, mastication and possibly other as yet unknown physiological process, 5) the use of leaves in the research, 6) the grinding of leaves prior to feeding and 7) the use of mature grass hay as a basal diet. I will discuss each of the foregoing and in some cases refer the reader to the manuscript where a rational has been discussed.

1) There is no question mammals adapt to changes in diet and, as in the ruminant, changes in diet generally require a change in the microbial population in the digestive tract. The lambs used were born and reared to weaning on a sagebrush-short grass range and might, although doubtful, have consumed sagebrush. We had a limited supply of sagebrush leaves and twig tips and, unfortunately, were not able to provide the lambs with an extended adaptation period. This was a considered decision taking into account the length of the feeding period, the levels of sagebrush to be fed, the number of lambs and how long an adaptation period could be needed. Yes, our decision was to shorten the adaptation period, a decision we at the time wished we didn't need to make but did. Since that time a study (unpublished at this time) using in vitro procedures and administering sagebrush leaves via rumen cannula for 32 consecutive days was conducted. Also, research on the amount of essential oil from 2 sources of big sagebrush necessary to influence an in vitro formentation was conducted.

2) The relationship between in vivo and in vitro results using similar substrates and inoculum can be rather varied. However, the data from our in vivo study suggested a strong influence of sagebrush on dry matter digestibility of the diet fed lambs. Thus, we chose to move to in vitro studies to evaluate the influence of sagebrush per se and the extracted essential oils on dry matter disappearance. Initial studies, using from $0-30 \%$ of the substrate dry matter as sagebrush, did not produce a depression in in vitro dry matter disappearance. Thus the statement by Ngugi et al. (1995). "However, the relationship between in vivo digestibility and in vitro digestibility for big sagebrush needs additional study." Subsequent research using extracted oil demonstrated oil added to in vitro systems equivalent to that found if $60 \%$ of the substrate dry matter were sagebrush was necessary to cause a depression in microbial activity measured as gas production. Why levels of sagebrush in in vitro systems don't produce results similar to the same levels in vivo raises many questions, a few of which Dr. Welch mentions.

The "adaptation" study previously mentioned produced results similar to the other in vitro study-no apparent influence of 32 days of adaptation on the ability of inoculum to influence in vitro dry matter disappearance. This in retrospect should not be surprising considering the results of the in vitro research using various levels of added oils.

3) Dr. Welch is concerned about the mention of sagebrush having "highly lignified, indigestible cell walls...". This is merely a matter of reference since leaves from many plants (alfalfa, clovers, and many forbes) contain relatively little lignin. Mentioning lignin in sagebrush was not, as implied by Dr. Welch, an attempt to denigrate sagebrush but was simply a statement of what we and others have found.

4) The loss of volatiles during prehension, mastication and other physiological processes is a very interesting and important area of research we discussed in detail. We have considered many possible modes for this to occur but, unfortuantely, it is hard to explain our in vivo results using several of the mitigating adaptive adjustments suggested by Dr. Welch. We, in our research, had no evidence of adaptation. This is not to say some species have, through time developed adaptive mechanisms that allow them to consume sagebrush with little or no negative impact.

5) The use of leaves and twig tips in our research was simply a matter of being able to obtain this material readily and further it was felt this was a reasonable representation of what sheep would consume, especially during periods when snow cover prevented exposure to most other forms of vegetation.

6) As mentioned in the paper, sagebrush was ground while frozen in a pre-chilled wiley mill to make it difficult for sheep to be highly selective when receiving a ground hay basal diet. The procedure used to grind the sagebrush is commonly used to reduce particle size of fresh material containing volatile compounds (a good example is silage). Again, this is not to say some small amount of the volatiles are not lost. Some volatiles, albeit small amounts, may be lost but the extracted oil used in our research and estimates of amounts found in our sagebrush were obtained from samples ground while frozen.

7) Lastly, Dr. Welch expressed concern over the use of "mature grass" as the basic diet in our research. He asks "How much 
mature grass do wintering animals of western rangelands such as mule deer, pronghorn antelope, sage grouse, pygmy rabbits, etc. consume?" First, Dr. Welch may have lost sight of the fact we were studying sheep. Our concern is what happens when snow covers most vegetation other than sagebrush and sheep move from consuming cured-in-the-stand grass to sagebrush to meet their daily dietary needs. At least in Wyoming this is not uncommon. Secondly, we were not proposing our research should in any way be applicable to non-domestic rangeland mammals, although Dr. Ngugi, in the review of literature in his dissertation, does address estimates of intakes of sagebrush by season of the year for several species of wildlife.

Finally, I believe as scientists we must be objective in our approach to solving problems and answering questions. On several occasions my colleagues and I are referred to as being biased and on more than one occasion, through innuendo, we are implied to be opponents of big sagebrush and "attack" sagebrush. On the other hand the commentator states "As a self-proclaimed defender of big sagebrush....". My colleagues and I in no way intended our work as an attack on sagebrush nor docs it represent a bias on our part. I guess in the final analysis the comments represent one person's opinions and hopeful the reader will take the manuscript for what it is - a report of research results several scientists felt should he shared with others. (Although there are several errors in the comments the one that is most confusing to the unsuspecting readers is where I presume Dr. Welch meant Ngugi et al. (1995) but said Nagagi et al. (1995). 